\title{
LIETUVOS KŪNO KULTŪROS AKADEMIJOS STUDENTŲ SOCIALINĖS INTEGRACIJOS, POŽIŪRIO İ SVEIKATĄ IR SVEIKĄ GYVENSENĄ KAITA
}

\author{
Elvyra Grinienė, Pavelas Zachovajevas \\ Lietuvos kūno kultūros akademija, Kaunas, Lietuva
}

\begin{abstract}
Elvyra Grinienè. Profesorè medicinos mokslų habilituota daktarè. Lietuvos kūno kultūros akademijos Sveikatos ir fizinio aktyvumo katedros
\end{abstract} profesorè. Mokslinių tyrimų kryptis — ugdymo proceso ir fizinio aktyvumo itaka moksleivių sveikatai.

\section{SANTRAUKA}

Tyrimo tikslas - išsiaiškinti, kiek 2007 m. pakito Lietuvos kūno kultūros akademijos (LKKA) studentu socialinès integracijos lygis, požiūris i savo sveikata ir sveikq gyvensena, palyginti su $2000 \mathrm{~m}$. duomenimis.

2007 m. vasario ménesị apklausti 177, 2000 m. vasario mènesí-198 LKKA studentai. Apklausai naudota uždaro tipo anoniminé anketa, sudaryta pagal HBSC tarptautinés apklausos standartizuota klausimyna, adaptuota studentu apklausai (Grinienè, 2000). Studentu socialinès integracijos lygis vertintas balais pagal A. Eder (1990). Studentu požiūris i sveikata ir sveika gyvensenq vertintas pagal atsakymu i klausimus dažnį.

Daugumos LKKA studentu socialines integracijos lygis geras: 2007 m. sieke 72,9\%, 2000 m. - 71,5\%. Ir 2007, ir 2000 m. socialinès integracijos lygis nepriklausè nuo kurso bei studiju programos, nors per šl laikotarpi pastebimai kito atskiru dalyku programos, ju dèstymo seka. Dauguma studentujautèsi visiškai arba pakankamai sveiki. 2007 m. mažiau studentu nei 2000-aisiais nurodè, kad jiems trūksta žiniu, kaip sveikai gyventi. Dauguma studentu nurodè, kad apie sveika gyvensenq studiju metais igijo daugiau žiniu. Nepaisant to, LKKA studentu sportavimas labiausiai priklausè nuo studiju programose sportavimui skirto laiko, tarp ju buvo kasdien rūkančiu ir vartojančiu svaigiuosius gèrimus. 2007 m. kasdien rūkančiuju nors ir nedaug, bet padaugejo. Dauguma studentu tiek 2000, tiek 2007 m. buvo apsvaigę nuo alkoholio bent kartq ar dažniau.

Per 7 metus daugumos LKKA studentu integracijos lygis nepakito - liko geras, jie panašiai jautèsi visiškai arba pakankamai sveiki. 2007 m. daugiau studentu nurodè, kad jiems pakanka žiniu sveikai gyventi. Studentu, kurie rūpinosi savo sveikata, turëjo daugiau žiniu ir manè, kad sveikata priklauso nuo gyvensenos, daugiau buvo tarp tu, kuriu socialinès integracijos lygis geras, kurie aktyviai sportavo, nerūkè, ju namu aplinka buvo gera.

Raktažodžiai: sveikata, socialinès integracijos lygis, fizinis aktyvumas, žalingi ipročiai.

\section{IVADAS}

$\mathrm{D}$ auguma akademinio jaunimo studijas pradeda iškart baigę vidurinę mokyklą, su jau savaip suformuotais gyvensenos ipročiais, požiūriu i sveikatą ir rūpinimusi ja. Pakitusi socialinė aplinka, studijų specifika, padidejusios savarankiškumo galimybès, susijusios su naujais išbandymais, galimybėmis keisti požiūrị, elgsena, gyvenimo būdą. Kaip rodo tyrimai, šiandieniniam akademiniam jaunimui trūksta socialaus aktyvumo, juos vargina ekonominès ir bendravimo problemos, menka edukacinė kokybė (Bostanci et al., 2005), vis mažiau jaunus žmones veikia kultūra (Oksur, Malhan, 2005). Tarp akademinio jaunimo daugèja sveikatai rizikingos elgsenos atvejų (Von Ah et al., 2005; Von Bothmer, Fridlund, 2005). Dėl stresų ir menkos fizinès veiklos padažnėjo nusiskundimu 
sveikata (Bray, Bora, 2004). Vyresnių kursų studentai skundžiasi miego stoka (Lee et al., 2007). Nurodoma, kad studentai savo sveikatą gali pagerinti tobulindami valgymo igūdžius, rinkdamiesi kokybiškesni maistą, vadovaudamiesi propaguojamais sveikos gyvensenos principais (Alves, Boog, 2007). Akcentuojamas profesionalus požiūris ị sveikatos ugdymą nuo pirmo kurso (Olckers et al., 2007).

Apklausos rodo, kad nors nemaža dalis Lietuvos studentų mano, kad ju sveikata gera, kas dešimtas ir daugiau nurodo vienokius ar kitokius nusiskundimus sveikata bei negalavimus (Vaščila, 2003, Skirius, Karpavičienè, 2005; Grinienè, 2006). Nemaža dalis studentų neturi išsiugdę sveikatai naudingu ipročių. Didžioji dauguma Vilniaus pedagoginio universiteto studentu nurodo, kad ju mityba yra nesveika, nepakankamas ir judejjimo aktyvumas (Proškuvienè ir kt., 2006), Kauno technologijos universiteto studentų sveikatos būklè vis blogeja (Grobovienè ir kt., 2003), Lietuvos žemès ūkio universiteto studentai linkę išbandyti sveikatą žalojančius veiksnius (Vaščila ir kt., 2007). Keturių aukštujų mokyklų trečių kursų studentų apklausa parodè, kad studentai vis dar sunkiai renkasi sveikatą tausojantị ir stiprinanti gyvenimo būdą (Griniené, 2006). Nors Lietuvoje studentu sveikata tyrinejjama, vykstanti studiju pertvarka, nacionalinès sveikatos politikos ir strategijos kaita veikia jų požiūrị i sveikatą, elgseną, gyvensenos būdą. Todèl kartotiniai studentų sveikatos, tolesnio sveikos gyvensenos ugdymo aukštojoje mokykloje problemų tyrimai išlieka aktualūs.

Tyrimo tikslas — išsiaiškinti, kiek $2007 \mathrm{~m}$. pakito Lietuvos kūno kultūros akademijos (LKKA) studentų socialinès integracijos lygis, požiūris i savo sveikatą ir sveiką gyvenseną, palyginti su $2000 \mathrm{~m}$. duomenimis.

Uždaviniai:

1. Atskleisti LKKA studentų socialinès integracijos lygi priklausomai nuo studijų programos ir kurso.
2. Išsiaiškinti, kiek po septynerių metų pakito LKKA studentų požiūris į savo sveikatą ir sveiką gyvenseną.

3. Nustatyti, ar yra ryšys tarp studentų socialinès integracijos, požiūrio ị sveikatą ir sveikos gyvensenos.

\section{TYRIMO ORGANIZAVIMAS IR METODAI}

2000 m. vasario mėnesi apklausti 198 LKKA studentai: 100 Sporto edukologijos (SE) ir 98 Sporto biomedicinos (SB) fakultetu, 113 I kurso ir 85 IV kurso. $2007 \mathrm{~m}$. vasario mèn. apklausti 177 LKKA studentai: 75 SE ir 102 SB fakultetu, 97 I kurso ir 80 IV kurso. Tirtoji imtis svarbiausiu demografinių kintamujų požiūrių tenkina reprezentatyvumo reikalavimus. Apklausai naudota uždaro tipo anoniminè anketa, sudaryta pagal tarptautinès apklausos standartizuotą klausimyną (HBSC), adaptuotą studentų apklausai (Grinienè, 2000). Studentu socialinès integracijos lygis vertintas pagal atsakymus i 4 klausimus su 17 teiginių. Atsakymas kaip labai geras vertintas surinkus 3 balus, vidutinis $-1-2$ balus, menkas -0 balu (Eder, 1990). Studentų požiūris ì savo sveikatą vertintas pagal atsakymus i 9 klausimus su 30 teiginiu, sveika gyvensena - pagal atsakymus i 7 klausimus su 32 teiginiais. Statistine duomenu analizė atlikta Excel 2003 programa. Skirtumo reikšmingumas vertintas $\chi^{2}$ kriterijumi. Duomenys laikyti patikimais, kai $\mathrm{p}<0,05$.

\section{REZULTATAI}

Iš 1 lentelès matyti, kad daugumos studentu socialinès integracijos lygis buvo geras, tik ketvirtadalio vidutinis ir pavieniais atvejais menkas. Per septynerius metus studentu skirstinys pagal socialinès integracijos lygi liko panašus, nepaisant

\begin{tabular}{|c|c|c|c|c|c|c|c|c|c|c|c|c|c|}
\hline Tiriamieji & Visi a & $\begin{array}{l}\text { klaus- } \\
\text { ji }\end{array}$ & Va & inai & Me & ginos & & Irso & IV & urso & & $7 \mathrm{~m}$. & $\begin{array}{l}1 \text { lentelè. Stu- } \\
\text { dentų skirsti- } \\
\text { nys pagal soci- }\end{array}$ \\
\hline Metai & 2007 & 2000 & 2007 & 2000 & 2007 & 2000 & 2007 & 2000 & 2007 & 2000 & SE & SB & ir $2000 \mathrm{~m}$. (\%) \\
\hline Geras & 72,9 & 71,2 & 81,1 & 71,8 & 65,5 & 71,3 & 75,4 & 69,8 & 69,6 & 72,8 & 69,4 & 75,7 & Pastaba. Skirtu- \\
\hline Vidutinis & 22,6 & 27,0 & 15,5 & 25,0 & 29,3 & 28,5 & 20,0 & 28,6 & 26,1 & 25,3 & 27,8 & 18,9 & $\begin{array}{l}\text { rodiklių } 2007 \\
2000 \mathrm{~m} \text {. patik }\end{array}$ \\
\hline Menkas & 4,5 & 1,8 & 3,4 & 3,2 & 5,2 & 0,2 & 4,6 & 1,6 & 4,3 & 1,9 & 2,8 & 5,4 & mas, $\mathrm{p}<0,05$. \\
\hline
\end{tabular}




\begin{tabular}{|l|l|l|l|l|l|l|l|l|l|l|}
\hline \multicolumn{1}{|c|}{ Tiriamieji } & \multicolumn{2}{r|}{$\begin{array}{l}\text { Visi apklaus- } \\
\text { tieji }\end{array}$} & \multicolumn{2}{c|}{ Vaikinai } & \multicolumn{2}{c|}{ Merginos } & \multicolumn{2}{c|}{ I kurso } & \multicolumn{2}{c|}{ IV kurso } \\
\hline $\begin{array}{l}\text { Atsakymai } \\
\text { i klausimus }\end{array}$ & $\mathbf{2 0 0 7}$ & $\mathbf{2 0 0 0}$ & $\mathbf{2 0 0 7}$ & $\mathbf{2 0 0 0}$ & $\mathbf{2 0 0 7}$ & $\mathbf{2 0 0 0}$ & $\mathbf{2 0 0 7} *$ & $\mathbf{2 0 0 0}$ & $\mathbf{2 0 0 7} *$ & $\mathbf{2 0 0 0}$ \\
\hline $\begin{array}{l}\text { Kaip vertina savo } \\
\text { sveikata? }\end{array}$ & & & & & & & & & & \\
\hline Visiškai sveikas & 40,1 & 44,3 & 56,5 & 44,4 & 29,6 & 44,2 & 50,5 & 25,8 & 33,2 & 62,0 \\
\hline $\begin{array}{l}\text { Pakankamai } \\
\text { sveikas }\end{array}$ & 52,0 & 51,7 & 36,2 & 51,7 & 62,0 & 51,6 & 42,3 & 70,0 & 55,7 & 34,0 \\
\hline Nelabai sveikas & 7,9 & 4,0 & 7,3 & 3,9 & 8,4 & 4,2 & 7,2 & 4,2 & 11,1 & 4,0 \\
\hline $\begin{array}{l}\text { Ar pakanka žiniu } \\
\text { sveikai gyventi? }\end{array}$ & $* *$ & $* *$ & $* *$ & $* *$ & $* *$ & $* *$ & $* *$ & $* *$ & $* *$ & $* *$ \\
\hline Pakanka & 43,3 & 20,6 & 36,2 & 20,9 & 50,9 & 19,7 & 28,2 & 19,1 & 60,2 & 22,0 \\
\hline Ne visada & 54,9 & 55,8 & 62,1 & 51,2 & 47,2 & 61,2 & 68,8 & 59,1 & 31,8 & 57,1 \\
\hline Trūksta & 1,8 & 23,6 & 1,7 & 27,9 & 1,9 & 19,1 & 3,0 & 21,8 & 8,0 & 20,9 \\
\hline
\end{tabular}

2 lentelè. Požiūris į savo sveikatą 2007 ir 2000 m. (\%)

\begin{tabular}{|l|l|l|l|l|l|l|l|l|l|l|}
\hline \multicolumn{1}{|c|}{ Tiriamieji } & $\begin{array}{l}\text { Visi apklaus- } \\
\text { tieji }\end{array}$ & \multicolumn{2}{c|}{ Vaikinai } & \multicolumn{2}{c|}{ Merginos } & \multicolumn{2}{c|}{ I kurso } & \multicolumn{2}{c|}{ IV kurso } \\
\hline $\begin{array}{l}\text { Atsakymai } \\
\text { i klausimus }\end{array}$ & $\mathbf{2 0 0 7}$ & $\mathbf{2 0 0 0}$ & $\mathbf{2 0 0 7 *}$ & $\mathbf{2 0 0 0 * *}$ & $\mathbf{2 0 0 7 *}$ & $\mathbf{2 0 0 0 * *}$ & $\mathbf{2 0 0 7}$ & $\mathbf{2 0 0 0}$ & $\mathbf{2 0 0 7}$ & $\mathbf{2 0 0 0}$ \\
\hline Dabar nerūko & 78,6 & 78,7 & 68,2 & 67,2 & 85,1 & 86,5 & 78,4 & 77,8 & 73,3 & 78,7 \\
\hline $\begin{array}{l}\text { Rūko karta per } \\
\text { savaitę }\end{array}$ & 7,3 & 10,0 & 10,1 & 15,0 & 5,6 & 6,3 & 7,2 & 13,7 & 6,7 & 10,0 \\
\hline $\begin{array}{l}\text { Rūko kiekvieną } \\
\text { dieną }\end{array}$ & 14,1 & 11,3 & 21,7 & 17,8 & 9,3 & 7,2 & 14,4 & 8,5 & 20,0 & 11,3 \\
\hline $\begin{array}{l}\text { Buvo apsvaige } \\
\text { nuo alkoholio: }\end{array}$ & 8,5 & 9,0 & 7,2 & 9,0 & 9,2 & 10,1 & 10,3 & 6,1 & 4,2 & 11,2 \\
\hline Niekada & 15,3 & 20,5 & 4,4 & 12,2 & 22,2 & 31,5 & 12,4 & 20,2 & 20,0 & 20,9 \\
\hline Karta & 55,9 & 58,3 & 50,7 & 58,0 & 59,3 & 55,2 & 55,7 & 64,2 & 55,9 & 53,0 \\
\hline Kelis kartus & 20,3 & 12,2 & 37,7 & 20,8 & 9,3 & 3,2 & 21,6 & 9,5 & 19,9 & 14,9 \\
\hline $\begin{array}{l}\text { Daugiau nei kelis } \\
\text { kartus }\end{array}$ & & & & & & & & & & \\
\hline
\end{tabular}

3 lentelè. Studentų požiūrio ị rūkymą ir alkoholio vartojimą skirstinys (\%)

Pastaba. * - skirtumas tarp vaikinų ir merginų, rūkančiu ir apsvaigusiu nuo alkoholio, $2007 \mathrm{~m}$. rodikliu patikimas $(\mathrm{p}=0,0001) ; * *$ - skirtumas tarp vaikinų ir merginu, rūkančių ir apsvaigusiu nuo alkoholio, $2000 \mathrm{~m}$. rodikliu patikimas $(\mathrm{p}=0,007)$.

to, kad per ši laikotarpi pastebimai kito atskiru dalyku programos, jų dèstymo seka. Socialinès integracijos lygis buvo panašus vaikinų ir merginų, pradedančių (I kurso) ir baigiančiu (IV kurso) studijas, Sporto edukologijos (SE) ir Sporto biomedicinos (SB) fakultetų studentu. Taigi LKKA studentų socialinès integracijos lygis studijų metais iš esmès nekito.

Iš 2 lentelès matyti, kad dauguma studentuc jautėsi visiškai arba pakankamai sveiki. Panašiai savo sveikatą studentai vertino 2007 ir 2000 m., vienodai vaikinai ir merginos. $2007 \mathrm{~m}$. savo sveikata geriau vertino pirmakursiai $(p=0,008)$ ir SE fakulteto studentai $(p=0,001)$. Savo sveikata $2007 \mathrm{~m}$. gerai rūpinosi 33,3\% apklaustujų, o manè, kad galètu ja geriau rūpintis, $52,5 \%$. Gerai savo sveikata rūpinosi daugiau vaikinu ( 37,7 ir $30,6 \%$ ), o kad galètu geriau rūpintis nurodè daugiau merginų $(58,3$ ir $43,5 \%)(p=0,04)$, panašiai atitinkamai manè SB ir SE fakultetuc studentai $(\mathrm{p}=0,0001)$.

2007 m. mažiau nei pusei apklaustujų žinių, kaip sveikai gyventi, pakako, o ju nepakako tik $1,8 \%$, tuo tarpu $2000 \mathrm{~m}$. žiniu pakako kas penktam studentui $(\mathrm{p}=0,001)$. Tai pastebèta lyginant 2007 ir $2000 \mathrm{~m}$. vaikinu ir merginu ( $\mathrm{p}=0,0001)$, pirmakursiu ir ketvirtakursiu atsakymus $(\mathrm{p}=0,0001)$. Be to, $2007 \mathrm{~m}$. apklaustu vaikinu ir merginu atsakymai patikimai nesiskyrè. $2007 \mathrm{~m}$. žiniu apie sveikatą, igytu mokykloje $(6,5 \pm 0,2)$ ir akademijoje $(7,1 \pm 0,3)$, vertinimas dešimtbale sistema patikimai nesiskyrè. Aukštesnis balas, rodantis, kad studiju metais apklaustieji igijo daugiau žinių apie sveikata, pastebetas lyginant pirmakursių $(6,5 \pm 0,3)$, ketvirtakursių $(8,6 \pm 0,2)$, SB 


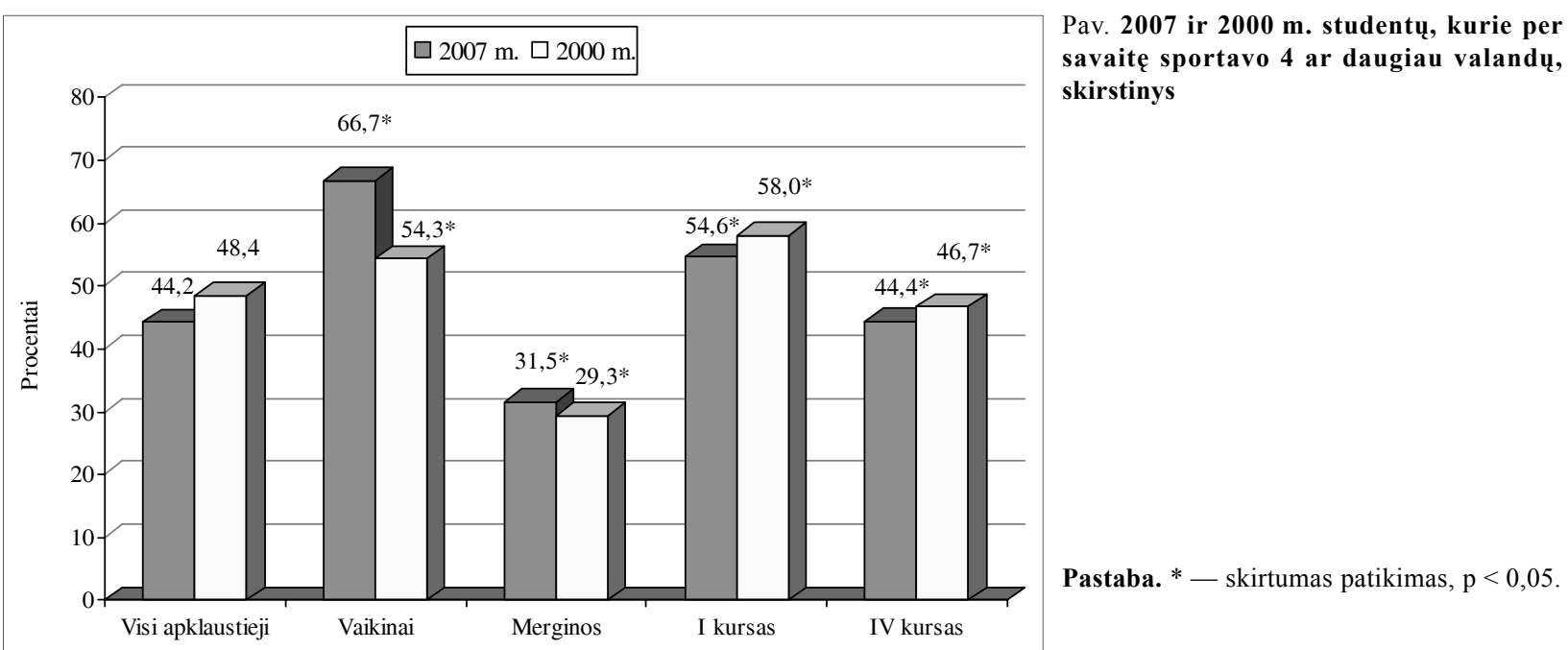

$(8,4 \pm 0,2)$ ir $\operatorname{SE}(6,9 \pm 0,2)$ fakultetu studentuc atsakymus $(\mathrm{p}=0,01)$.

2007 m. apklaustieji pagal 100 procentų vertinimo skalę nurodè, kad sveikata vidutiniškai $71,7 \pm 1,1 \%$ priklausè nuo gyvensenos. Vidurkis skyrèsi tik lyginant skirtingu fakultetų studentų atsakymus: $\mathrm{SE}-67 \pm 0,2 \%, \mathrm{SB}-73 \pm 0,4 \%$ $(\mathrm{p}=0,02)$. Nepaisant supratimo, kad sveikata priklauso nuo gyvensenos ir tam pakanka turimu žinių, studentai per mažai laiko skyrè sportui, tarp jų buvo rūkančių ir vartojančių alkoholị.

Iš 1 paveikslo matyti, kad 2007 ir $2000 \mathrm{~m}$. taip, kad suprakaituotų ir padažnėtų kvėpavimas, 4 ar daugiau valandų per savaitę sportavo pusė studentú. Vaikinu sportavo daugiau nei merginu $(\mathrm{p}=0,016)$, pirmakursiu daugiau nei ketvirtakursių ( $\mathrm{p}=0,034), 2007 \mathrm{~m}$. SE fakulteto studentų daugiau $(64,4 \%)$ nei SB $(14,4 \%)(p=0,012)$. 2007 m. 57,7\% apklaustuju sportavo tik mokomųjų pratybų akademijoje metu, o $2000 \mathrm{~m}$. - 42,6\%, sporto klubuose atitinkamai 32,2 ir 36,0\%.

Tarp apklaustuju nepopuliari rytinè mankšta. Kasdien rytais mankštinosi: 2007 m. - 1,7\%, 2000 m. — 4,6\%, retkarčiais — atitinkamai 29,4 ir 45,3\%. Taigi LKKA studentu sportavimas labiausiai priklausè nuo studiju programose sportavimui skirto laiko.

Iš 3 lentelès matyti, kad dauguma 2007 ir 2000 m. apklaustų LKKA studentų nerūkè, o rūkančių kasdien 2007 m., lyginant su 2000 m., nors ir nepatikimai, tačiau padaugèjo. Panašiai nurodè ir vaikinai, ir merginos, pirmakursiai ir ketvirtakursiai. Pagal atsakymus kiekvieną dieną rūkančių daugiau buvo vaikinu nei merginų $(\mathrm{p}=0,01)$. Rūkančių vienodai buvo I ir IV kurso, SE (13,3\%) ir SB (11,5\%) fakultetų apklaustujų. Dauguma studentų 2007 ir $2000 \mathrm{~m}$. buvo apsvaigę nuo alkoholio bent kartą ar dažniau. Tik 8,5\% 2007 m. ir 9,0\% $2000 \mathrm{~m}$. niekada nebuvo apsvaigę nuo alkoholio. Vaikinų ir merginų, apsvaigusių nuo alkoholio, skirstinys pagal dažni patikimai skyrèsi (2007 m. - p =0,0001, 2000 m. - p =0,007) ir nepriklausė nuo apklausos datos, studijų programos, trukmès.

2007 m. studentų apklausos duomenų koreliaciné analizè parodé, kad yra sąsajų tarp apklaustujų socialinès integracijos lygio, studentu požiūrio ị sveikatą ir sveiką gyvenseną. Patikimas koreliacinis ryšys nustatytas tarp socialinès integracijos lygio ir studentų rūpinimosi savo sveikata $(\mathrm{p}=0,005)$, jų turèjimo pakankamai žinių apie sveikatą ( $\mathrm{p}=0,002)$, galvojimo, kad sveikata priklauso nuo gyvensenos $(\mathrm{p}=0,03)$, kai apklaustieji sportavo po 4 ar daugiau valandu per savaitę $(p=0,02)$. Žinių apie sveikatą koreliacinis ryšys patikimas tų studentų, kurie aktyviai lankè mokomąsias pratybas akademijoje ar lankè sporto klubus ( $\mathrm{p}=0,001)$, buvo gera namų aplinka $(p=0,05)$. Koreliacinis ryšys patikimas ir tarp svarbos sveikai gyventi bei aktyvaus sportavimo $(\mathrm{p}=0,05)$, požiūrio ị rūkymą $(\mathrm{p}=0,03)$ ir alkoholio vartojimą $(\mathrm{p}=0,05)$.

\section{REZULTATŲ APTARIMAS}

Nagrinėjant sveikatos klausimus visada reikia atkreipti dėmesi i gyvenseną, nes nuo jos labiausiai priklauso mūsų sveikata. Sveikatą lemia gebèjimas kontroliuoti save ir bendrauti su aplinkiniais, pakankamas fizinis aktyvumas, tabako bei svaigalų nevartojimas ir aplinka (Alves, Boog, 2007).

Socialinè integracija yra svarbi studentu gyvensenos sudedamoji dalis, susijusi su nauja socializacijos pakopa, studijų sèkme ir būsimo gyvenimo būdo pasireiškimo dalimi. Atliktas tyrimas parodé, kad daugumos LKKA studentu 
socialinès integracijos lygis $2007 \mathrm{~m}$., lyginant su 2000-aisiais, iš esmès nepakito ir liko geras. Panašus socialinès integracijos lygis buvo tarp vaikinų ir merginų, tarp pradedančiujų ir baigiančiujų studijas, nepriklausomai nuo studiju krypties ir trukmès. Studijos iš esmès nepakeite daugumos LKKA studentų gebejimo bendrauti: jie išliko pakankamai atviri, patiklūs ir draugiški. Tik nedidelè dalis studentų turèjo mažiau artimu draugų, jiems sunku buvo susirasti naujų, dažniau jautèsi vieniši. Apklausos duomenys atskleidè, kad yra ryšys tarp socialinès integracijos lygio ir rūpinimosi savo sveikata, galvojimo, kad sveikata priklauso nuo gyvensenos. Tai atitiktu autorių, tyrinejjusių studentu gyvenimo kokybę ir protinę bei socialinę sveikatą (Vaez, Laflamme, 2003; Extremera, Fernandez-Berrocal, 2006), panašius vertinimus.

Apklausos rodo, kad studentu nuomonè apie savo sveikatą yra gera (Von Ah et al. 2005; Alves, Boog, 2007). Dauguma Lietuvos studentų mano, kad yra visiškai ar pakankamai sveiki (Vaščila, 2003; Grinienė, 2006; Proškuvienè ir kt., 2006). Tai atitiktų 2007 ir $2000 \mathrm{~m}$. tirtu LKKA studentu nuomonę apie savo sveikatą. Nors autoriai, kurie tyre studentų nusiskundimus ir objektyviai vertino sveikatos sutrikimus, atkreipia demesi $\mathfrak{i}$ tai, kad studentai nepakankamai vertina savo sveikata, turi vienokiu ar kitokiu psichosomatiniu nusiskundimų, yra linkę sirgti vienomis ar kitomis ligomis ir dèl sveikatos sutrikimų nedalyvauja fizinèse pratybose (Grinienè, 2006; Proškuvienè ir kt., 2006; Liaudanskas ir kt., 2007; Vaščila ir kt., 2007). $2007 \mathrm{~m}$. tik trečdalis apklaustų studentų nurodè, kad sveikata rūpinasi gerai ir pusè jų manè, kad galètų rūpintis geriau, nors žinių, kaip sveikai gyventi, daugumai pakako arba ne visada pakako. 2007 m., palyginti su 2000-aisiais, manančių, kad jiems pakanka žinių sveikai gyventi, padaugejjo (beveik dvigubai), ypač merginu ir ketvirto kurso studentų. Apie sveikatą žinių, igytų akademijoje, balas ketvirtakursių, lyginant su pirmakursiais, pastebimai buvo geresnis. Taigi galimybė labiau rūpintis sveikata buvo, nors ne visi apklaustieji ja pasinaudojo.

Didžiausią poveiki sveikatai turi fizinis aktyvumas. Atliktas tyrimas parodè, kad 2007 ir 2000 m. sportuojančiuju taip, kad suprakaituotu ir padažnėtų kvėpavimas, 4 ar daugiau valandu per savaitę buvo pusè studentų. Iš jų dauguma sportavo tik mokomuju pratybu metu akademijoje. Sporto klubuose sportavo trečdalis studentu. Matyt, dauguma apklaustujų manè, kad pakan- kamai fiziškai lavinasi per studiju programose numatytas pratybas. Kai kurie autoriai teigia, kad fizinis aktyvumas yra vienas iš svarbiausių sveikos gyvensenos veiksnių, kad mažiau fiziškai aktyvūs studentai greičiau nuvargsta, nèra gera ju psichologinè būsena (Bray, Bora, 2004). Lietuvos aukštosiose mokyklose studentų fizinis aktyvumas yra nepakankamas, fizinè saviugda menka, jų fiziniam aktyvumui trukdo negebejimas derinti sporto pratybų su studijomis, dažnai jie neturi noro, valios ir energijos domètis kitomis laisvalaikio praleidimo formomis (Vaščila ir kt., 2007). Panaši situacija ir kitose šalyse (Stock et al., 2001; Kramer et al., 2004; Bostanci, et al., 2005). Todèl, norint pagerinti studentú sveikatą, reikia daugiau dèmesio skirti fiziniam aktyvumui.

Žalingi ipročiai - sveikatą griaunantys gyvensenos veiksniai. Daugelis mokslininkų, tyrinejjusių studentų sveikatą ir sveikos gyvensenos ipročius, nurodo, kad tarp studentu gausèja rizikingos elgsenos atvejų, dažnai jiems trūksta žinių apie sveiką gyvenseną (Stock et al., 2001; Von Ah et al., 2005). Dažnai rūko, vartoja svaigiuosius gèrimus Švedijos universitetu studentai (Von Bothmer, Fridlund, 2005), rūkymas ir svaigalu vartojimas paplitę tarp Turkijos studentų, ypač tų, kurių socialinès-ekonominès sąlygos yra prastos (Oksuz, Malhan, 2005), Vokietijos studentai dažnai linkę vartoti svaigiuosius gèrimus ir narkotikus, pasigenda kovos priemonių prieš sveikatai žalingus veiksnius (Stock et al., 2001; Kramer et al., 2004). Lietuvos atskirose aukštosiose mokyklose pastebimas rūkalių gausèjimas. K. Kardelio ir kt. (2001) duomenimis, rūko nuo 9,0 iki 15,4\% studentų, kasdien arba keletą kartu per dieną vartoja svaigiuosius gèrimus nuo 23,0 iki 28,1\%. R. Proškuvienė ir kt. (2006) nustatè, kad rūko $50,4 \%$ vyru ir $33,4 \%$ moteru, nuo alkoholio daug kartų buvo apsvaigusių atitinkamai 56,3 ir 23,5\%, vartojusių nelegalius narkotikus - 36,8 ir 12,2\%. Šie duomenys kelia nerima. Atliktas tyrimas parodè, kad 2007 m., lyginant su 2000-aisiais, rūkančių kasdien LKKA studentų padaugejjo. Ir 2007 , ir $2000 \mathrm{~m}$. dauguma studentų buvo apsvaigę nuo alkoholio bent vieną kartą ar dažniau. Pastebėtas koreliacinis ryšys tarp svarbos sveikai gyventi ir rūkymo bei alkoholio vartojimo. Per septynerius metus sportuojančiu studentu skaičius sumažèjo, o rūkančių padidèjo. Padaugèjo ir svaigalus vartojančiu skaičius. Todèl LKKA ir apskritai visose aukštosiose mokyklose būtina propaguoti sveiką gyvenseną, teikti atitinkamas rekomendacijas bei jas igyvendinti. 


\section{IŠVADOS}

1. Daugumos LKKA studentų socialinès integracijos lygis buvo geras, panašus 2007 ir $2000 \mathrm{~m}$., nepriklausè nuo studijų programos bei kurso.

2. Dauguma studentų panašiai 2007 ir $2000 \mathrm{~m}$. jautėsi visiškai arba pakankamai sveiki. $2007 \mathrm{~m}$. savo sveikata geriau vertino pirmakursiai ir SE fakulteto studentai.

3. $2007 \mathrm{~m}$. daugiau nei 2000 -aisiais studentų nu- rodè, kad jiems pakanka žinių sveikai gyventi. Visgi 2007 m. padaugejo rūkančiuju, o apsvaigusių nuo alkoholio bent vieną kartą ar daugiau liko panašus skaičius kaip 2000-aisiais.

4. $2007 \mathrm{~m}$. studentŭ, kurie rūpinosi savo sveikata, turèjo daugiau žinių ir manè, kad sveikata priklauso nuo gyvensenos, daugiau buvo tarp tu, kuriu socialinis integracijos lygis geras, kurie aktyviai sportavo, nerūké, turejjo jaukią namu aplinka.

\section{LITERATŪRA}

Von Ah, D., Eberts, S., Ngamvitroj, A., Park, N., Kang, D. H (2005). Predictors of health behaviours in college students. Journal of Advanced Nursing, 50 (1), 111-112.

Alves, H. J., Boog, M. C. (2007). Food behavior in student residence hall: A setting for health promotion. Revista de Saude Publica, 41 (2), 197-204.

Von Bothmer, M. J., Fridlund, B. (2005). Gender differences in health habits and motivation for a healthy lifestyle among Swedish university students. Nursing and Health Sciences, 7 (2), 107-118.

Bostanci, M., Ozdel, O., Oguzhanoglu, N. K. et al. (2005). Depressive symptomatology among university students in Denizli, Turkey: Prevalense and sociodemografic correlates. Croatian Medical Journal, 46 (1), 96-100.

Bray, S. R., Bora, H. A. (2004). Transition to university and vigorous physical activity: Imlications for health and psychological well-being. Journal of American College Health, 52 (4), 181-189.

Eder, A. (1990). Risk factor loneliness. On the interrelations between social integration, hapiness and heath in 11-, 13-, 15 year old schoolchildren in 9 European countries. Health Promotion, 5 (1), 19-33.

Extremera, N., Fernandez-Berrocal, P. (2006). Find more like this emotional intelligence as predictor of mental, social and physical health in university students. Spanish Journal of Psychology, 9 (1), 45-51.

Grinienè, E. (2000). Lietuvos kūno kultūros akademijos studentų požiūris į sveikatą. Socialiniu-humanitariniu mokslu vaidmuo universitetinio ugdymo sistemoje: moksliniu straipsniu rinkinys (pp. 218-220). Kaunas: Akademija.

Grinienè, E. (2006). Studentų savos sveikatos vertinimas ir požiūris i sveiką gyvensena. Ugdymas. Kūno Kultūra. Sportas, 1 (60), 10-17.

Groboviene, V., Skužinskienè, A., Šapokienè, I., Štarienè, D. (2003). Kauno technologijos universiteto pirmo kurso studentu sveikatos problemu studijos. Dvasines vertybès žiniu visuomeneje: tarptautinè moksline konferencija: mokslo darbai (pp. 218-220). Kaunas: Akademija.

Kardelis, K., Misevičiene, L., Šaferis, V. (2001). Studentu gyvensena ir požiūris į sveikatos stiprinimą. Ugdymas Küno Kultūra Sportas, 2 (39), 22-26.

Kramer, A., Prufer-Kramer, L., Stock, C., Tshiananga, J. T. (2004). Differences in health determinants between inter- national and domestic students at a German university. Journal of American College Health, 53 (3), 127-132.

Lee, Y. S., Chien, K. L., Chen, H. H. (2007). Lifestyle risk factors associated with fatigue in graduate students. Journal of the Formosan Medical Association, 106 (7), $565-572$.

Liaudanskas, S., Liaugminienè, R., Baranauskaitè, A. (2007). LŽŪU studenčių požiūris i sveiką gyvenseną. Kultūra - ugdymas - visuomenè: mokslo darbai, 2, 245-249. Kaunas: Akademija.

Oksuz, E., Malhan, S. (2005). Socioeconomic factors and health risk behaviours among university students in Turkey: Questionaire study. Croatian Medical Journal, 46 (1), 66-73.

Olckers, L., Gibbs, T. J., Duncan, M. (2007). Developing health science students into integrated health professionals: a practical tool for learning. Medical Education, 15, 7 (1), 45.

Proškuvienè, R., Zlatkuvienè, V., Černiauskienė, M. (2006). Studentu — būsimuju pedagogu gyvensena ir požiūris i sveikatą. Visuomenés sveikata, 2 (33), 73-78.

Skirius, J., Karpavičienė, A. (2005). Studentų plaukiku ir rankininkų ligos bei traumos: ju paplitimas ir struktūra. Kultūra - ugdymas - visuomenè: mokslo darbai, 1 , 344-347. Kaunas: Akademija.

Stock, C., Wille, I., Kramer, A. (2001). The health of students during their education. Gesundheiitswesen, 63 (1), $556-559$.

Vaez, M., Laflamme, L. (2003). Health behaviors, selfrated health and quality of life: A study among first year Swedish university students. Journal of American College Health, V 51 (4), 156-162.

Vaščila., V. (2003). Lietuvos žemès ūkio universiteto pirmo kurso studentu sveikatos savianalizè. Dvasines vertybès žiniu visuomeneje: tarptautine mokslinè konferencija: mokslo darbai. Kaunas: Akademija. 265-267.

Vaščila, V., Siaurodinas, A., Vyskupaitis, E., Raupelis, A. (2007). Jaunimo sveikatos savianalizė ir sveika elgsena. Kultūra - ugdymas - visuomené: mokslo darbai, 2, 250-253. Kaunas: Akademija. 


\title{
ALTERNATION OF SOCIAL INTEGRATION AND ATTITUDES TOWARDS HEALTH AMONG THE STUDENTS AT LITHUANIAN ACADEMY OF PHYSICAL EDUCATION
}

\author{
Elvyra Grinienè, Pavelas Zachovajevas \\ Lithuanian Academy of Physical Education, Kaunas, Lithuania
}

\begin{abstract}
The aim of the research was to determine the level of alternation of social integration, attitudes towards health among the students at the Lithuanian Academy of Physical Education (LAPE) in 2000-2007.

The survey conducted in February, 2007, included 177 LAPE students: 75 students from the Faculty of Sports Education (SE) and 102 from the Faculty of Sports Biomedicine (SB); 97 students were in the 1st year of studies and $80-$ in the 4 th year of studies. 198 students $(\mathrm{SE}-100$ and SB $-98,1$ st year of studies - 113, 4th year of studies - 85) participated in the survey in 2000. The anonymous and closedended questionnaire used in the survey was formed according to PSO international survey standardized questionnaire and an adapted questionnaire of conducted student surveys. Students' social integration was assessed in points according to their daily interaction with other people (Eder, 1990): 0 points for low integration, $1-2$ points for medium integration and 3 points for high integration. The attitude to health was assessed on the basis of the frequency in students' answers. The data were compared to the data of similar surveys.

High social integration was observed in the majority of respondents: $2007-72.9 \%$, in $2000-71.5 \%$. The level of social integration did not depend on the year of studies and major field, though substantial changes in separate years of studies were observed between 2000 and 2007. The majority of students perceived themselves as healthy: in $200792.1 \%(2000$ - 96\%) of the respondents indicated that they were in perfect health or healthy enough. In 2007 more students from the 1st year (50.5\%) indicated that they were in perfect health than in the 4th year $(33.3 \%), p=0.008$, SB $(60.5 \%)$ than SE $(37.8 \%), p=0.01$. In 2000 more respondents indicated the lack of knowledge for healthy living than in 2007 (23.6\% and 1.8\%). Majority of respondents indicated that they acquired more knowledge of healthy living during their studies at LAPE and agreed that their health depended on healthy lifestyle. In spite of the fact that time for practicing sports mainly depended on the planned time for sports during lectures, there were some respondents who practiced alcohol drinking and smoking among the students of LAPE. Half of the respondents indicated that they practiced sports 4 hours and more per week in 2000 and $2007.57 .7 \%$ of the respondents practiced sports during lectures in 2007 (42.6\% in 2000), trained in sports clubs 32.2 and $36.0 \%$ respectively. There was a slight increase in the number of smokers $(11.3 \%$ in 2000 and $14.1 \%$ in 2007). The majority of the respondents had used alcoholic drinks once or more in 2000 and 2007. There were more respondents who smoke or drank alcohol daily among men than women $(\mathrm{p}<0.01)$.

Students with high social integration level and satisfactory attitude to personal health more cared about their health, had more knowledge and agreed that their health depend on healthy lifestyle.
\end{abstract}

Keywords: health, level of social integration, physical activity, harmful habits.

Gauta 2008 m. gegužès 1 d.

Received on May 1, 2008

Priimta 2008 m. birželio $18 \mathrm{~d}$.

Accepted on June 18, 2008

\author{
Elvyra Grinienè \\ Lietuvos kūno kultūros akademija \\ (Lithuanian Academy of Physical Education) \\ Sporto g. 6, LT-44221 Kaunas \\ Lietuva (Lithuania) \\ Tel +370 37302638 \\ E-mail e.griniene@lkka.lt
}

